WellBeing International

WBI Studies Repository

9-2007

\title{
Animal Mind: Science, Philosophy, and Ethics
}

Bernard E. Rollin

Colorado State University

Follow this and additional works at: https://www.wellbeingintlstudiesrepository.org/acwp_asie

Part of the Animal Studies Commons, Comparative Psychology Commons, and the Other Animal Sciences Commons

\section{Recommended Citation}

Rollin, B. E. (2007). Animal mind: science, philosophy, and ethics. The Journal of Ethics, 11(3), 253-274.

This material is brought to you for free and open access by WellBeing International. It has been accepted for inclusion by an authorized administrator of the WBI Studies Repository. For more information, please contact wbisr-info@wellbeingintl.org.

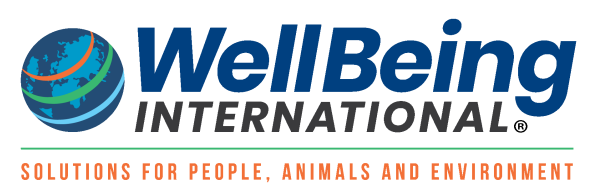




\title{
Animal Mind: Science, Philosophy, and Ethics
}

\author{
Bernard E. Rollin \\ Colorado State University
}

\section{KEYWORDS}

animal consciousness, animal ethics, animal mind, behaviorism, scientific change

\begin{abstract}
Although 20th-century empiricists were agnostic about animal mind and consciousness, this was not the case for their historical ancestors - John Locke, David Hume, Jeremy Bentham, John Stuart Mill, and, of course, Charles Darwin and George John Romanes. Given the dominance of the Darwinian paradigm of evolutionary continuity, one would not expect belief in animal mind to disappear. That it did demonstrates that standard accounts of how scientific hypotheses are overturned - i.e., by empirical disconfirmation or by exposure of logical flaws - is inadequate. In fact, it can be demonstrated that belief in animal mind disappeared as a result of a change of values, a mechanism also apparent in the Scientific Revolution. The "valuational revolution" responsible for denying animal mind is examined in terms of the rise of Behaviorism and its flawed account of the historical inevitability of denying animal mentation. The effects of the denial of animal consciousness included profound moral implications for the major uses of animals in agriculture and scientific research. The latter is particularly notable for the denial of felt pain in animals. The rise of societal moral concern for animals, however, has driven the "reappropriation of common sense" about animal thought and feeling.
\end{abstract}

Given the tendency of 20th-century empirically-oriented philosophers and biological and psychological scientists to be agnostic if not downright atheistic about animal mind, it is somewhat surprising to find that their historical ancestors entertained no such reservations. John Locke, for example, responding to Rene Descartes' claim that animals were simply machines, makes patent his belief in their mental lives. Somewhat inconsistently, he allows that they can reason, yet without the ability to abstract. After affirming that perception is indubitably in all animals, ${ }^{1}$ and thus that they have ideas, he asserts that if they have any ideas at all, and are not bare machines (as some Cartesians would have them), we cannot deny them to have some reason.

It seems as evident to me, that they do some of them in certain instances reason, as that they have sense; but it is only in particular ideas, just as they received them from their senses. They are the best of them tied up within those narrow bounds, and have not (as I think) the faculty to enlarge them by any kind of abstraction. ${ }^{2}$

In another passage, he mocks those who would assert "that dogs or elephants do not think, when they give all the demonstration of it imaginable, except only telling us that they do so."3 
But it is David Hume who, among empiricists, most unequivocally affirmed the existence of animal thought and mentation. Arguably the greatest skeptic in the history of philosophy, denying the ultimate knowability of mind, body, God, causation, the past or the future, Hume nonetheless extends no doubt to animal mind. In Section XIV of the Treatise, "Of the Reason of Animals," he affirms "next to the ridicule of denying an evident truth, is that of taking much pains to defend it; and no truth appears to me more evident, than that beasts are endowed with thought and reason as well as men. The arguments are in this case so obvious, that they never escape the most stupid and ignorant." 4

The certainty of animal thought is affirmed throughout subsequent empiricist British philosophy, with Jeremy Bentham and John Stuart Mill drawing moral consequences from animals' ability to feel pain and thus of necessity their being included in the scope of utilitarian moral concern. ${ }^{5}$ Bentham's famous remark was

Other animals, which, on account of their interests having been neglected by the insensibility of the ancient jurists, stand degraded into the class of things. ... The day has been, I grieve it to say in many places it is not yet past, in which the greater part of the species, under the denomination of slaves, have been treated ... upon the same footing as ... animals are still. The day may come, when the rest of the animal creation may acquire those rights which never could have been withholden from them but by the hand of tyranny. The French have already discovered that the blackness of skin is no reason why a human being should be abandoned without redress to the caprice of a tormentor. It may come one day to be recognized that the number of legs, the villosity of the skin, or the termination of the os sacrum, are reasons equally insufficient for abandoning a sensitive being to the same fate. What else is it that should trace the insuperable line? Is it the faculty of reason, or perhaps, the faculty of discourse? ... The question is not, Can they reason? nor, Can they talk? but, Can they suffer? Why should the law refuse its protection to any sensitive being? ... The time will come when humanity will extend its mantle over everything which breathes ...6

Mill in turn affirmed that "the reasons for legal intervention in favor of children apply not less strongly to the case of those unfortunate slaves - the animals."7

Thus we see that from Locke through the Utilitarians there exists the assumption in empiricism of animal mentation, from Hume's claim of animal reason to Bentham's and Mill's affirmation of animals' ability to feel pain. The scientific culmination of this stance on animal consciousness, however, is reached in the works of Charles Darwin. Darwinian science gave new vitality to ordinary commonsense notions that attributed mental states to animals, but which had been assaulted by Catholics and Cartesians. For Darwin, the guiding assumption in psychology was one of continuity; so the study of mind became comparative, as epitomized by Darwin's marvelously blunt title for his 1872 work, The Expression of the Emotions in Man and Animals, a title which brazenly hoists a middle finger to the Cartesian tradition, since Darwin saw emotion as inextricably bound up with subjective feelings. Furthermore, in The Descent of Man of the previous year, Darwin had specifically affirmed that "there is no fundamental difference between man and the higher animals in their mental facilities," and that "the lower animals, like man manifestly feel pleasure and pain, happiness, and misery." In the same work, Darwin attributed the entire range of subjective experiences to animals, taking it for granted that one can gather data relevant to our knowledge of such experiences. Evolutionary theory demands that psychology, like anatomy, be comparative, for life is incremental, and mind did not arise de novo in man, fully formed like Athena from the head of Zeus. 
Darwin was not of course content to speculate about animal consciousness. He explicitly turned over much of his material on animal mentation to a trusted spokesman, George John Romanes, who in turn published two major volumes, Animal Intelligence (1882) and Mental Evolution in Animals (1884), both of which richly evidence phylogenetic continuity of mentation. In his preface to Animal Intelligence, Romanes acknowledges his debt to Darwin, who, in his words,

not only assisted me in the most generous manner with his immense stores of information, as well as with his valuable judgment on sundry points of difficulty, but has also been kind enough to place at my disposal all the notes and clippings on animal intelligence which he has been collecting for the last forty years, together with the original manuscript of his wonderful chapter on "Instinct." This chapter, on being recast for the "Origin of Species," underwent so merciless an amount of compression that the original draft constitutes a rich store of hitherto unpublished material. ${ }^{9}$

While Romanes' work focuses mainly on cognitive ability throughout the phylogenetic scale, he also addresses emotions and other aspects of mental life, all of which, for a Darwinian, ought to evidence some continuity across animal species.

In addition to the careful observations he made, Darwin also pursued a variety of experiments on animal mentation. Darwin placed great emphasis on verifying any data subject to the slightest question. Towards this end, he, for example, contrived some ingenious experiments to test the intelligence of earthworms, a notion which he clearly felt was far beyond the purview of anecdotal information, and which was sufficiently implausible as to require controlled experimentation. These experiments, now virtually forgotten, occupy some thirty-five pages of Darwin's The Formation of Vegetable Mould Through the Action of Worms with Observations on their Habits (1886). The question Darwin asked was whether the behavior of worms in plugging up their burrows could be explained by instinct alone or by "inherited impulse" or chance, or whether something like intelligence was required. In a series of tests, Darwin supplied his worms with a variety of leaves, some indigenous to the country where the worms were found, others from plants growing thousands of miles away, as well as parts of leaves and triangles of paper, and observed how they proceeded to plug their burrows, whether using the narrow or the wide end of the object first. After quantitative evaluation of the results of these tests, Darwin concluded that worms possess rudimentary intelligence, in that they showed plasticity in their behavior, some rudimentary "notion" of shape, and the ability to learn from experience. Darwin is no romantic anthropomorphist; he clearly distinguishes the intelligence of the worms from the "senseless or purposeless" manner in which even higher animals often behave, as when a beaver cuts up logs and drags them about when there is no water to dam, or a squirrel puts nuts on a wooden floor as if he had buried them in the ground. ${ }^{10}$

As Darwin's work quickly became the regnant paradigm in biology and psychology, one would expect that the science of animal mentation would have steadily evolved during the subsequent century and a half as a subset of evolutionary biology. Strangely enough, this is not the case. Despite Darwin's influence, animal mentation disappeared as a legitimate object of study, not only in a Europe influenced by Cartesianism, but in the Anglo-American world as well.

Before we turn to the remarkable story of how this occurred, a story that shakes the foundation of how science believes itself to change, it is worth mentioning that Darwin's work inspired a spurt of concern about the moral status of animals. While Darwin himself did not follow out in the moral realm the logic of attributing the evolution and continuity of consciousness to animals, save for occasional comments like "the love for all living creatures is the most noble attribute of man,"11 a number of his contemporaries did, most notably E. P. Evans in his Evolutional Ethics and Animal Psychology (1898) and Henry Salt in Animal Rights Considered in Relation to Social Progress (1892). The obvious extension of moral concern 
to animals as continuous with humans phylogenetically and mentally seems to have been forestalled by a self-serving interpretation of Darwin affirming that, since humans were "at the top of the evolutionary pyramid," they were "superior" to lesser beings and thus we did not need to worry about them morally.

Scientific common sense - my term for the uncritical ideology associated with science for well over 100 years and believed by most scientists - decrees that there are only two ways that established scientific theories or hypotheses can be overturned. The first and most obvious way is through empirical disconfirmation. We gather data or do experiments showing that what was believed is factually falsified. Thus we may believe that "all swans are white" until we find a black swan, or that stress causes ulcers until we found that the primary cause was helicobacter pylori. ${ }^{12}$ The secondary way of rejecting a theory or hypothesis is by showing that it is conceptually or logically flawed. Thus Albert Einstein demonstrated that Issac Newton's account of absolute space and time was incoherent, for its postulation required of us the ability to measure absolute simultaneity, yet what events we call "simultaneous" depend on the observer measuring them. In a similar way Bertrand Russell showed Gottlob Frege's definition of number to generate logical absurdity. ${ }^{13}$ This form of disconfirmation is of course much rarer.

From the time of Darwin (and even before, as we have seen), the existence and knowability of animal mentation was taken as axiomatic through the early years of the 20th-century. But, after 1920, and even today, it is difficult to find British or U.S. psychologists or classical European ethologists, who would accept that view. ${ }^{14}$ The obvious question which arises, of course, is whether the assumption of animal mind was empirically disconfirmed, or else found to be conceptually flawed. The surprising answer is neither. There was no empirical disconfirmation of animal consciousness nor was there any conceptual/logical flaw found in its postulation. In fact, far from being disproved, the knowability of animal consciousness was disapproved, disvalued, banished by a valuational revolution cloaked in rhetoric about how to make psychology a "real" science, and all of science allegedly wholly empirical.

In actual fact, there is quite a significant history of science changing in virtue of valuational considerations, rather than by the accepted methods delineated above; it is perhaps surprising that the Scientific Revolution can be so viewed! To begin with, we must recall that all human cognitive enterprises, of which science is of course a paradigm case, rest on certain foundational presuppositions, what Aristotle called "archai." As in the transparent case of geometry, all such activities must make certain assumptions in order to function. Again, as in geometry, one cannot prove the assumptions, for it is upon these assumptions that the possibility of proof itself rests. If one could prove the assumptions, it would of necessity be on the basis of other assumptions, which must themselves either be taken for granted or based in other assumptions, etc., ad infinitum. That is not of course to suggest that one cannot criticize the assumptions; we have already pointed to examples of logically flawed assumptions in Newton and Frege. But we have also seen that in the case of the assumption that animals possess and evidence mentation and feeling, no such incoherence was discovered.

Are assumptions in science discarded for reasons other than demonstrable logical fallaciousness? Are they adopted for reasons other than to replace fallacious ones or to better account for recalcitrant data? One is compelled to assert that this is indeed the case; they may change for valuational reasons as well. One need look no further than the Scientific Revolution to buttress this claim. It is well known that the Scientific Revolution inaugurated by Galileo, Descartes, Newton and others, indeed marked a major discontinuity with medieval/Aristotelian science. Aristotelian science was concerned with explaining the world which we find through our senses, which were assumed to be a mainly reliable source of information about that world. And, as the senses tell us, the world is a world of qualitative differences - of things alive and not alive, hot and cold, wet and dry, solid and liquid, good and bad, beautiful and ugly. To be adequate, science must do justice to that world. Aristotle specifically affirms that there thus can be no one master science of everything; each thing must be explained according to its own kind, and each 
domain of scientific inquiry rests upon assumptions uniquely appropriate to it. A science of inert matter can never serve to explain the behavior of living things; this is a conceptual and methodological necessity based in the patent empirical differences we find in the world. Thus Aristotle definitively rejects the Platonic notion of an underlying reality which required only one language - that of mathematics. The only reason mathematics fits everything, says Aristotle, is that it is so vague and general as to be vacuous, like the "interesting paper" comment which professors at a loss to say anything else scrawl on student essays. For Aristotle, science should tell us what is unique to a domain, not what is common to all domains.

The science of Galileo, et al., thoroughly rejects the Aristotelian story. It is not that the revolutionaries discovered empirical facts which falsify or disconfirm the core of Aristotle's account. Any empirical facts (i.e., data gathered by the senses) are grist for Aristotle's mill, or are compatible with Aristotle's worldview, since they, by definition and of necessity bespeak a world of qualitative differences. What the proponents of revolution must rather do is disvalue certain facts, and ways of looking at the facts which Aristotle holds dear! Aristotle disvalues the quantitative dimensions of the world. The revolutionaries stand him on his head and glorify the quantitative, while trivializing the qualitative. This is not disconfirmation. It is rather a difference in seeing, brought about by a difference in valuing, in much the same way that a son and his parents might look very differently at his potential spouse - he stressing sex appeal and excitement, they stressing reliability and good sense. Looking at the same woman, they thus find very different characteristics in their respective lists of her strengths and faults.

The Scientific Revolutionaries value mathematical unity over sensory diversity; universal intelligibility over fragmented intelligibility; reason over experience; Plato over Aristotle; geometry over natural history; physics over biology. And as Paul Feyerabend ${ }^{15}$ and others have pointed out, they defend their approach at least as much by appeal to value as to fact.

Consider, for example, the classic case of Descartes' defense of the quantitative approach in his Meditations. ${ }^{16}$ His tack is to disvalue the senses as a reliable source of information about reality, striking directly at Aristotle's notion of "what you see is what you get." Descartes' argument essentially proceeds as follows. He provides numerous examples where the senses deceive us. Nothing in sense experience is absolutely certain; we are all familiar with the sorts of mistakes the senses make. Since we can be wrong about any sensory experience, we could conceivably be wrong about every such experience and if we could be wrong about every such experience, we should categorically reject the senses as a source of information. From this basis, Descartes proceeds to deduce what one could not be wrong about, his own existence, and eventually, a priori, geometrical knowledge of the world of the sort favored by the New Science.

As soon as one scrutinizes this argument, it is patent that it does not logically compel the abandonment of Aristotelianism, anymore than new data could empirically compel the rejection of Aristotelianism. Descartes' argument is flawed in many ways. For one thing, by parity of reasoning, one can construct the following argument: Since one could be right (as well as wrong) about any type of empirical knowledge, one could be right (as well as wrong) about every item of empirical knowledge, therefore one should accept all such knowledge - clearly a fallacious argument isomorphic to Descartes. ${ }^{17}$ Second, as Hume points out, we might be wrong in any of our mathematical calculations and proofs (e.g., by misreading a symbol or simply by erring as we do when learning geometry). Thus, even if Descartes is correct about the infallibility of his self-knowledge, that same infallibility does not extend to mathematical physics, both because we can make mathematical errors and, even more important, because we need to apply our mathematical physics to real world situations, and for this we need to rely on sense experience. Descartes' reply is that a benevolent deity would not deceive us, at least regularly - a response equally appropriate for the Aristotelian against whom Descartes marshalled his arguments in the first place. 
Thus Descartes, Galileo, and other figures in the Scientific Revolution neither falsify the Aristotelian approach empirically, nor do they show it to be conceptually flawed at root in ways which could not be turned back on their own positions. Once we realize this, we are in a position to understand that the orthodox notion of how scientific ideas are abandoned will not always stand up. It appears that scientific ideas can change not only because of disconfirming data or because of the discovery of basic logical flaws, but also because of the rise of new values which usher in new philosophical commitments or new basic assumptions. Thus, in the case we have been discussing, a variety of new values, ranging from preference for Plato over Aristotle by a group of prominent intellectuals to greater concern about precision in the prediction of projectile movement because of the advent of artillery, to a penchant for reductionism over pluralism, led to a change in basic assumptions about what science should be doing and how it should be doing it. In the same vein, it has been pointed out that new technology or tools can determine even basic theoretical approaches and assumptions in science, notably in medicine, which situation accords with neither of the classical accounts of scientific change, but does fit better with our valuational account. New technologies are valued sufficiently to subordinate medical approaches and assumptions to their use. ${ }^{18}$

It is within this new category that we will attempt to place the abandonment of the common sense/Darwinian approach to animal mentation. It appears that the view that animals have subjective experiences and that these could be studied was given up not because it did not generate fruitful research programs - it surely did, in the hands of people like Darwin and Romanes. Nor was it given up because it did not explain or allow us to predict animal behavior - it surely did. Nor was it shown to be logically inconsistent or incoherent. Rather, it was abandoned because of some major valuational upheavals and concerns.

What values come into play that worked against the knowability of animal consciousness in the early 20th-century? Most important, perhaps, was the marvelous salesmanship of John B. Watson in selling Behaviorism. ${ }^{19}$ Watson sold to scientists, but also sold to the general public. He was one of the rare scientists who loved to talk to reporters about the social utility of the science he advocated. Watson promised nothing less to his peers than creating a new psychology as credible as physics and chemistry!

One has only to examine Watson's own work to see that he was attempting to sell a new philosophicalvaluational package. In "Psychology as the Behaviorist Views it," Watson's 1913 manifesto, he urges psychology to "throw off the yoke of consciousness." ${ }^{20}$ Only by so doing can psychology become a "real science." By concerning itself with consciousness, "it failed signally ... to make its place in the world as an undisputed natural science" like physics and chemistry. ${ }^{21}$ To be a "real science," it must behave like a real science and study what is "observable." Thus he writes "Can image type be experimentally tested and verified? Are recondite thought processes dependent mechanically upon imagery at all? Are psychologists agreed upon what feeling is?"22 Watson assumes, but does not demonstrate, that the answer to all these questions is negative. What is observable is behavior. What we find in the world are "stimulus and response, habit formations, habit integrations and the like." 23 "I believe we can write a psychology, define it as Pillsbury [i.e., as the science of behavior], and never go back upon our definition: never use the terms consciousness, mental states, mind, content, introspectively verifiable, imagery, and the like." ${ }^{24}$

Note that Watson does not prove that we should do this; he merely affirms that psychology will be more like physics and chemistry if we do and thus advocates it. ${ }^{25}$ To the objection that the abandonment of consciousness is a very heavy price to pay, a violation of what we all know to be part of the furniture of the universe (some would say the best-known part of all the furniture), Watson said little, except that he did not "care" about consciousness. ${ }^{26}$ In most of his written work, Watson did not go so far as to say explicitly that there are no such things as consciousness, mental images, and the like; but it is clear that 
this is his bottom line. Throughout his life, he contended that thoughts, images and the rest were "implicit behavior," small muscular movements in the larynx or other organs which we would be able to detect if we had a more advanced technology. Watson, in essence, paradoxically held that "[w]e do not have thoughts, we only think we do." Subjective mental states are at best dispensable psychic trash, at worse non-existent. Watson's own deepest mental states are inaccessible to us, of course, not least since he is dead. But he was certainly interpreted as I have just outlined by his contemporaries and co-workers such as Karl Lashley.

If Behaviorism was to be significantly different from other approaches which preceded it, including the Darwin-Romanes approach, it must deny the reality of consciousness in humans and animals, or at least its knowability. In this regard, Watson is his own version of a consistent Darwinian. In fact, in a bizarre dialectical turn in the 1913 essay, he accuses those who argue for a phylogenetic continuum of consciousness of anthropocentrism, because "it makes consciousness as the human being knows it, the center of reference for all behavior," ${ }^{27}$ just as Darwinian biology was anthropocentric in attempting first and foremost to describe the evolution of Homo sapiens.

Behaviorism played well to the general public, especially the U.S. public, because it promised a science that would birth a technology - the ability to control and shape behavior; with it we could rehabilitate criminals, educate children properly, produce a better society. With its contempt for genetic bases of behavior it fit perfectly into U.S. optimism about social engineering and the ability to shape humans, just as we conquered the frontier and shaped nature. This side of Behaviorism reached its culmination in the work of Watson's student, B. F. Skinner.

Behaviorism also fit well with other early 20th-century cultural tendencies, in particular with the reductive tendency manifest in that era to eliminate frills, excesses, and superfluities. This value may be found in diverse quarters: Arnold Schönberg's reaction against Richard Wagner and Gustav Mahler, and others; the Bauhaus reaction against excessive ornamentation in art and design; the rise of formalism in criticism. All express the same spirit which also invaded science in the form of Positivism. Thinkers like Ernst Mach, Albert Einstein, and later the logical positivists all sought to excise metaphysical and speculative baggage from science, to clearly delineate the realm of science as the realm of the empirical and observable, a tendency which had been part of science since Newton. ${ }^{28}$ Since animal consciousness could not become a direct empirical datum for us, it was automatically suspect on positivist grounds. Ironically, then, the phenomenalistic empiricism of Locke and Hume, which took animal consciousness as axiomatic, was stood on its head by their 20th-century successors. While scholars debate the influence that Logical Positivism had directly on Behaviorism, there is no doubt it at least created an environment highly congenial to the elimination of consciousness. Indeed, as I have argued in my Science and Ethics, ${ }^{29}$ positivism was a powerful force for removing both consciousness and ethics from legitimate scientific discourse, thereby accelerating what I have called "scientific ideology." There I trace the pernicious ethical consequences of this ideology for issues ranging from the treatment of research subjects to pain management in medicine, to science's image in the public mind.

To add insult to injury, behaviorist historians throughout the 20th-century wrote as if Watson was the logical and inevitable culmination of a variety of thinkers who succeeded Darwin. E. G. Boring, for example, cites Lloyd Morgan, Jacques Loeb, H. S. Jennings, E. B. Titchener, and Edward Thorndike as leading inevitability to Behaviorism. ${ }^{30}$ We all know that history is written by the victors. That notwithstanding, the tracing of psychology from Romanes to Watson is as egregious a distortion of the history of ideas I have ever encountered. In The Unheeded Cry, ${ }^{31}$ I did something quite heretical and actually read the psychologist's cited as leading to Watson. Amazingly enough, none of them ever even suggested the need for eliminating consciousness, indeed all presupposed it in their own writings. 
Consider, for example, the totally self-assured, unequivocal historical claim advanced by M. Marx and W. Hillix about the pivotal role of Conway Lloyd Morgan in paving the way for Behaviorism.

Romanes was demonstrating continuity by finding mind everywhere; Morgan also wished to demonstrate continuity, but suggested that it might be done as well if we could find mind nowhere. Morgan's appeal to simplicity and rejection of anthropomorphism would seem, from a modern perspective, to have made the development of a scientific behaviourism inevitable. ${ }^{32}$

They are here referring to the dogma (for Behaviorists) that Morgan's Canon eliminated consciousness. Sometimes erroneously seen as a special case of Occam's Razor, the Canon says with regard to an animal's behavior, "[i]n no case may we interpret an action as the outcome of the exercise of a higher psychical faculty, if it can be interpreted as the outcome of the exercise of one which stands lower in the psychological scale." ${ }^{33}$

Anyone who reads Morgan as a proto-Behaviorist has not read Morgan. The Canon is not only not intended to eliminate consciousness, it again presupposes consciousness. For Morgan believes unequivocally that if consciousness exists anywhere on the phylogenetic scale, it must exist everywhere, at least in simple form, even in bare nature! He is in fact a raving speculative metaphysician, a monist, a pan-psychist, a Spinozian, a believer that everything in nature has both a physical and psychological dimension. The Canon is simply meant to warn against confusing higher consciousness with lower, not to eliminate consciousness. Morgan's own words end any debate.

We have ... taken for granted the existence of consciousness, and the fact that there are subjective phenomena which we, as comparative psychologists, may study. We have also proceeded throughout on the assumption that subjective phenomena admit of a natural interpretation, as the result of a process or processes of development or evolution, in just the same sense as objective phenomena admit of such interpretation. ${ }^{34}$

The truth notwithstanding, for much of the 20th-century psychologists believed in the inexorable, logical, empirical victory of Behaviorism.

A number of questions obviously arise regarding the triumph of the behavioristic/positivistic view of consciousness. First of all, surely the denial of animal mentation flew directly in the face of ordinary common sense. Secondly, but of primary moral importance, what were the moral consequences of wholesale denial of animal mentation as far as the moral status and treatment of animals was concerned?

It was certainly the case that the denial of consciousness in animals (or for that matter, in humans) was inimical to the basic tenets of ordinary common sense. Ordinary common sense never would have denied consciousness in animals, and most certainly not in humans! And ordinary common sense would certainly have been surprised by the stance of science. But, then, as today, ordinary people did not pay much attention to the claims of science (scientific illiteracy was rife then as now), and, unless the science went directly counter to their religious beliefs, as in evolution, did not care much about what scientists believed. People might, for example, have heard the Einsteinian implication that a ray of light shining from a fast train did not go any faster than a ray of light coming from a stationary source, or of the twin paradox, or of Schroedinger's cat, and might even have experienced a moment of bafflement, but quickly shrugged and were not bothered - thinking "after all, scientists believe a lot of crazy things that strike us as odd."

As far as ethics and animals are concerned, the story is much more complex. In the first place, societal ethics (and the laws expressing it) vis à vis animal treatment were greatly limited - avoid deliberate, sadistic, intentional, unnecessary cruelty. But, by and large, animal treatment was not a moral issue; 
animals were to be provided with the necessities required for them to fulfill their human purposes. As we shall see, this was presuppositional to the nature of agriculture. Anything much beyond that was ignored. A beautiful example of this can be found in a 1905 textbook of veterinary surgery, wherein the author laments that although anesthesia has been available since the 1860's, it is rarely employed in veterinary surgery, with the occasional exception of the canine practitioner, whose clients valued their animals beyond the dictates of economic necessity. ${ }^{35}$ Thus surgery on food animals was traditionally performed under restraint ("bruticaine" as veterinarians called it) and to a significant extent is still done that way.

The moral implications of the denial of consciousness, even felt pain, to animals did not become apparent until the second half of the 20th-century, when social concern for animals began to surface, in the wake of major changes in the nature of animal use in agriculture and research, changes which significantly compromised animal wellbeing, and were abetted and perpetuated by the denial of animal consciousness among scientists, though not exclusively caused by that denial. In the mid-20th-century, animal use changed more precipitously and severely than had occurred since the advent of domestication. These changes ultimately had major impact on the belief in animal mind and on moral concern for animals, as we shall demonstrate. The most extreme change was in agriculture, by far the largest use of animals in society. Historically, agriculture was based in good husbandry or care, placing animals into the optimal environment for which they had evolved, and augmenting their natural ability to survive and thrive by provision of food during famine, water during drought, help in birthing, medical attention, and protection from predation. The relationship between humans and the animals they utilized for food, fiber, locomotion and power was a symbiotic one; both sides benefited from the relationship - what has been referred to as "the ancient contract." This is dramatically illustrated in the 23rd Psalm where the Psalmist, seeking a metaphor for God's ideal relationship to humans, can find no better one than the shepherd: "The lord is my shepherd, I shall not want. He leadeth me to green pastures; He maketh me to lie down beside still water; He restoreth my soul." In other words, we ask no more of God than what the good shepherd provides to the sheep. A lamb in ancient Judea could not survive without a shepherd; the shepherd depended on his flock. Without a shepherd, the animals would be decimated by predators, famine and drought. With the shepherd, they lived decent lives while giving us milk, wool, and meat. But while they lived, they lived well. Indeed, Christian iconography vividly makes this point and celebrates the contract by portraying Jesus as both shepherd and lamb.

To succeed in agriculture, one therefore had to know - and meet - animals' physical and psychological needs, for the agriculturalist did well if and only if the animals did well. Husbandry became ingrained as an ethical and prudential imperative; proper care was essential to success. The only articulated ethic for animals required was the prohibition against deliberate, unnecessary, sadistic cruelty or outrageous neglect such as not feeding and watering. This prohibition was meant to capture the sadists and psychopaths unmoved by self-interest, and is present in the Christian/Jewish sacred texts, in medieval thought (where it is recognized that those who are cruel to animals are likely to be cruel to people), and in the criminal laws of all civilized societies since 1800. It is very likely that what Hume had in mind when affirming that animal mind is obvious to all but the most benighted was animal users' understanding of their animals' physical and mental states, an understanding presuppositional to working with them. Even contemporary veterinary scientists, asked to explain to agnostic researchers how to recognize pain in animals, responded by saying, in essence, "ask those who work with them on a daily basis, and whose business it is to know." ${ }^{\text {"3 }}$

But this ancient contract did not survive the emergence of modern science-based technology. By the mid20th-century, agriculture had became industrialized, with academic departments of Animal Husbandry rapidly transmuted into departments of Animal Science, defined in textbooks as the "application of industrial methods to the production of animals." Industry supplanted husbandry and agriculture became 
exploitative rather than symbiotic. Whereas husbandry was about putting square pegs in square holes, round pegs in round holes, industrial agriculture forced square pegs into round holes, round pegs into oblong holes by use of "technological sanders" - antibiotics, vaccines, and air-handling systems. The animals' natures (telos as I call it, following Aristotle) could be circumvented, yielding economic benefit, and severing animal welfare from productivity, impossible under husbandry. And with the industrial model came the irrelevance of animal thoughts and feeling, yielding what Ruth Harrison aptly called "animal machines" - parts of a factory. Understanding of animal thought and feeling became superfluous, rather than pre-suppositional to productivity; animal misery no longer impacted on agricultural success. Bitterly attesting to this was the 1981 Council for Agricultural Science and Technology (CAST) report on the welfare of food animals, which defined "animal welfare" as the animals being productive according to the human reasons for keeping the animals. ${ }^{37}$

Thus the ideological skepticism about or rejection of animal mind inherent in behaviorism and positivism meshed well with the revolution in animal agriculture. But this was not all. The mid-20th-century also saw the rise of massive amounts of animal research and testing. Though clearly productive of considerable benefit to humans and to animals in general, unlike the situation in husbandry agriculture, being an animal in research provided no benefit to the animals upon whom research was performed; they were inflicted with diseases, fractures, wounds, burns, lesions with no offsetting benefit. And thus another major animal use emerged violative of the ancient contract.

In biomedicine, i.e., in biological and medical research, in psychological research, and even in veterinary research and in veterinary practice, the Cartesian model of animals as non-conscious, biological machines was regnant. Perhaps the most extreme morally relevant example of this was both the ideological denial and complete disregard of felt pain in animals, pain being, after all, what a recent book on the history of human pain and its control calls in its title "the worst of evils." The denial of pain is of seminal importance for two reasons. First of all, it is the state of awareness most related to moral concern, so much so, that we saw that Bentham and Mill made it the sine qua non for moral status. If pain is denied, a fortiori more complex and abstract morally relevant mental states such as "suffering" would logically be ignored. More generally, felt pain is a very basic biological safeguard for an organism. If one denies simple pain consciousness in an animal, one is logically bound to deny more complex mental states which require greater sophistication of consciousness.

That felt pain was denied or ignored for much of the 20th-century is easy to evidence objectively. As an architect and public advocate of federal legislation in the 1970's and 1980's that required control of pain in research animals, and which ultimately passed in 1985, I repeatedly came up against the denial of pain by the scientific community in both objectively documentable ways and in personal experiences, both sets of which are valuable to document.

On the objective front, until very recently the International Association for the Study of Pain (IASP) definition of "pain" required language as a necessary precondition for the ability to feel pain (shades of Descartes) thereby creating a belief that animals and neonatal humans (who until the 1990's were subjected to open heart surgery without anesthesia, restrained by paralytic drugs) could not be said to feel pain, i.e., did not. In essence, the same people who used animals as "pain models" for research turned around and denied that animals felt pain. Perfectly in harmony with this view was the complete failure of the first textbooks of veterinary anesthesia published in the U.S. to even acknowledge felt pain in animals or to raise any discussion of analgesia; anesthesia itself was tellingly referred to until very recently as synonymous with "chemical restraint." Finally, when I was asked by the U.S. Congress to evidence the need for a law requiring pain control for research animals, I did a literature search on "laboratory animal analgesia" and then on "animal analgesia," and was amazed to find only two papers, one of which said, in essence, that there ought to be papers! 
My personal experiences between 1976 (when we began to draft legislation) and 1985 (when it passed) better conveys the flavor of science's skepticism about felt pain. In 1979, I attended a conference on animal pain, where I debated a prominent scientist, with me defending the view that animals could feel pain, while he denied that claim. I thought we had enjoyed an amicable discussion until I returned to Colorado State University, whereupon I found out that after the debate he called the Dean of Veterinary Medicine and told him that I was "a viper in the bosom of biomedicine" who should not be allowed to teach in a veterinary program!

In 1982, I was asked to respond to a noted pain researcher who gave a speech at a conference saying that since the electro-chemical activity in the cerebral cortex of dogs was different from that of humans, and the cerebral cortex was the area that processed pain, the dog "did not really feel pain as humans did." My refutation was singularly brief. I asked him, "As a prominent researcher in pain, you do your research on dogs." "Yes," he replied. "You extrapolate your results to people?" I queried. "Of course," he said, "that is why I do my work." "In that case," I said, "either your speech is false or your life's work is."

Around 1980, when I was developing and pressing the federal legislation for laboratory animals, I was invited by AALAS (American Association for Laboratory Science) to discuss my reasons for supporting legislative constraints on science on a panel with half a dozen eminent laboratory animal veterinarians. By way of making my point, I asked them all to tell me what analgesic would be of choice for a rat used in a limb-crush experiment, assuming analgesia did not disrupt results that were being studied. The consensus response was, in essence, "How should we know? We do not even know for sure if animals feel pain!" I will return to this anecdote shortly.

At the American Veterinary Medical Association pain panel convened in 1986 after the laws passed by Dean Hiram Kitchen at the request of Congress in response to researcher complaints that they knew nothing of animal pain and thus could not obey the new law, I was asked to write the prologue to the report. I did, and presented it to the group. I approvingly pointed out that according to the great skeptical philosopher, Hume, few things are as obvious as the fact that animals have thoughts and feelings, and that this point does not escape "even the most stupid," as we quoted earlier. A representative from NIMH (Natural Institute of Mental Health) stood up indignantly and declared, "If we are going to talk mysticism, I am leaving," and did, never to return.

I could proliferate such stories, but one serves as a capstone. After the laws passed, Dr. Robert Rissler, head of USDA/APHIS, was in charge of writing regulations interpreting them. As he related at a conference, he was particularly concerned about the legal requirement (stipulated in the law) that accommodations for non-human primates, "enhance their psychological well-being." He told the audience that, as a veterinarian, he knew nothing of primates or "psychological well-being." So he went to the American Psychological Association Primatology Division, and asked for help. "Don't worry," he was told, "there is no such thing!" "Well there will be after January 1, 1987, whether you people help me or not," he astutely replied.

Science's ideological denial of consciousness, particularly pain, coupled with the ideological claim of science as "ethics-free," presented a formidable fortress, but one which burgeoning societal concern for animal treatment has successfully breached. As society has become conscious that new animal uses do not preserve the ancient fair contract with animals, and as interest in animals has been fueled by media coverage, philosophers (including Peter Singer, Tom Regan, Steve Sapontzis, and myself), celebrities, and by companion animals emerging as the paradigm for all animals in the social mind, society has demanded that laws ensure fair use. A total of 2,400 state laws relevant to animal welfare were floated in 2004. The laboratory animal laws we have described were a significant juggernaut in forcing the scientific community to "re-appropriate common sense" about animal pain and about other aspects of animal 
consciousness. These laws also mandate control of distress, which the USDA wisely did not stress until recently, in order to allow skepticism about animal pain to be overcome. My anesthesiologist colleague estimates that there are now between 5,000 and 10,000 papers on pain in animals.

With regard to animal agriculture, the situation is not as good. As we saw earlier, the industrial agriculture and agricultural science communities saw animal welfare as equated with productivity, were also doubtful about animal subjectivity, and further equated all forms of misery caused by production conditions with "stress," defined in terms of activation of the pituitary-adrenal axis. ${ }^{38}$ Agricultural science ignored the facts that "stress" is present during such pleasant experiences as sex and play, and the far more important fact proven by such scientists as John Mason ${ }^{39}$ and Jay Weiss ${ }^{40}$ that the stress response is modulated by animal conscious cognition, until well after this was known to other branches of science. In veterinary medicine, there is no knowledge or use to speak of regarding large animal analgesia, and in some cases, operative procedures are still done without anesthesia.

In Europe, ethical concerns about industrial agriculture, beginning in Britain in the 1960's, led gradually to the abolition of severe confinement practices, most dramatically represented by the Swedish law of 1988 that effectively banned animal agriculture of the sort still taken for granted in the U.S., and also to the study of animal consciousness and feelings with the realization that welfare is fundamentally about the animals' conscious experiences of what matters to them. ${ }^{41}$ The Swedish laws were followed by laws in other countries and European Union regulations eliminating such practices as veal crates and sow confinement.

In the U.S., where much of the population is naive about animal agriculture, believing that farms are still "Old McDonald's" pastoral, bucolic entities, concern for farm animals did not grow along with concern for research animals. There are, however, signs that consciousness and concern for the suffering of farm animals is growing - the rapid growth in sales of "humane" meat products; the success of restaurant chains such as Chipotle and groceries such as Whole Foods; the development of audits for basic farm animal welfare by corporate restaurants; the publication of surveys indicating public demand for laws constraining the use of farm animals. Obviously, such burgeoning public moral concern about farm animals will ramify in ever-increasing attention to farm animal pain and consciousness and to a demand for research into animal experience of the sort pioneered by Marian Dawkins and lan Duncan. ${ }^{42}$

In The Unheeded Cry, I recounted other indications of and causes for scientists' disaffection with the denial of consciousness. It is clear that these forces and neo-Darwinian interest in evolutionary continuity of consciousness will continue to drive renewed scientific interest in these issues. Even if it does not, social concern with animal treatment will, as ordinary common sense clearly now perceives the connection between welfare and consciousness and never doubts animal mentation, but rather is prone, if anything, to exaggerate its abilities.

In sum, the interplay between philosophy, science, and ethics, manifested in the history of the waxing and waning of the legitimacy of talking about animal mind, should serve as a salubrious counter to the standard story of how science changes. It is reasonable to predict that if societal concern for animal welfare continues to grow, and to demand practical ethical changes in animal use based in that concern, attention to the legitimacy of the study of animal mind will also continue to grow, particularly if there is research funding connected to such concern. As I once told Congress about science's disregard of animal pain: "If you appropriate a hundred million dollars for research into animal pain, few scientists will turn it down on ideological grounds." 
${ }^{1}$ John Locke, An Essay Concerning Human Understanding (New York: Dutton, 1871), p. 117.

${ }^{2}$ Locke, An Essay Concerning Human Understanding, p. 127.

${ }^{3}$ Locke, An Essay Concerning Human Understanding, p. 87.

${ }^{4}$ David Hume, A Treatise of Human Nature (Oxford: Oxford University Press, 1968), p. 176. The last sentence is presumably directed at Descartes.

${ }^{5}$ John Stuart Mill, in fact, was such a thoroughgoing empiricist that he thought mathematics to be inductively based!

${ }^{6}$ Jeremy Bentham, An Introduction to the Principles of Morals and Legislation (New York: Hafner Press, 1948), pp. 310-311.

7 John Stuart Mill, Principles of Political Economy, Volume 2, 3rd Edition (London: John W. Parker and Son, 1852), p. 546.

${ }^{8}$ Charles Darwin, The Descent of Man and Selection in Relation to Sex (New York: Modern Library, 1971), p. 448.

${ }^{9}$ George John Romanes, Animal Intelligence (London: Kegan Paul, Trench, Trubier and Co, 1978), p. X1.

${ }^{10}$ Charles Darwin, The Formation of Vegetable Mould Through the Action of Worms, with Observations on their Habits (New York: D. Appleton and Co., 1886), p. 95.

${ }^{11}$ Quoted in Richard Ryder, "Darwinism, Altruism and Painience," 1999 (Checked 16 November 2006 at www.ivu.org/ape/talks/ryder/ryder.htm).

${ }^{12}$ For simplicity, we are leaving aside the Quinean critique of straightforward verification or falsification.

${ }^{13}$ Bertrand Russell, The Principles of Mathematics (New York: W. W. Norton, 1996), Paragraph 500.

${ }^{14}$ See C. H. Schiller (ed.), Instinctive Behavior (New York: International Universities Press, 1957). This classic volume chronicles the first interactions of Anglo-American behaviorists with European ethologists of the school of Lorenz and Tinbergen. Though the two schools agreed about little else, they were of one mind in denying consciousness or its knowability in animals.

${ }^{15}$ Paul K Feyerabend, Against Method (Atlantic Highlands: Humanities Press, 1975).

${ }^{16}$ René Descartes, Meditations on First Philosophy, trans. L. J. Lafleur (Indianapolis: Bobbs-Merrill Educational publishing, 1960), Meditation One.

${ }^{17}$ I obtained this point from discussion with Arthur Danto.

${ }^{18}$ Stanley Reiser, Medicine and the Reign of Technology (Cambridge: Cambridge University Press, 1978).

${ }^{19}$ Let us recall that John B. Watson was a major force in developing modern advertising techniques.

20 John B. Watson, "Psychology as the Behaviorist Views it," Psychological Review 20 (1913), p. 459. Reprinted in W. Dennis (ed.), Readings in the History of Psychology (New York: Appleton-Century-Crofts, 1948), pp. 457-471. 
${ }^{21}$ Watson, "Psychology as the Behaviorist Views it," p. 461.

${ }^{22}$ Watson, "Psychology as the Behaviorist Views it," p. 462.

${ }^{23}$ Watson, "Psychology as the Behaviorist Views it," p. 463. In fact, of course, these are not directly observable; they are theoretical notions.

${ }^{24}$ Watson, "Psychology as the Behaviorist Views it," p. 463.

${ }^{25}$ The physics Watson admired, of course, is 19th-century physics. 20th-century physics soon soared beyond mechanism.

${ }^{26}$ Watson, "Psychology as the Behaviorist Views it," p. 466.

${ }^{27}$ Watson, "Psychology as the Behaviorist Views it," pp. 459-460.

28 The positivists also had political reasons and values which justified their hard empiricism - the elimination of meaningless but inflammatory rhetoric from political discourse.

${ }^{29}$ B. Rollin, Science and Ethics (Cambridge: Cambridge University Press, 2006).

${ }^{30}$ E. G. Boring, A History of Experimental Psychology (New York: Appleton-Century-Crafts, 1957).

${ }^{31}$ Bernard Rollin, The Unheeded Cry (Oxford: Oxford University Press, 1989).

${ }^{32}$ M. Marx and W. Hillix, Systems and Theories in Psychology (New York: McGraw-Hill, 1967), p. 168.

${ }^{33}$ C. L. Morgan, An Introduction to Comparative Psychology (London: Walter Scott, 1894), p 53.

${ }^{34}$ Morgan, An Introduction to Comparative Psychology, p. 323.

${ }^{35}$ L. A. Merillat, Principles of Veterinary Surgery (Chicago: Alexander Eger, 1906).

${ }^{36}$ D. B. Morton and P. H. M. Griffiths, "Guidelines on the Recognition of Pain, Distress, and Discomfort in Experimental Animals and an Hypothesis for Assessment," Veterinary Record (1985), pp. 431-436.

${ }^{37}$ Council for Agricultural Science and Technology, Scientific Aspects of the Welfare of Food Animals, Report Number 91, November 1981, p. 1.

${ }^{38}$ Catecholamines are a measure of short-term stress, and cortico-steroids of long term stress.

39 John W. Mason, "A Re-evaluation of the Concept of 'Non-Specificity' in Stress Theory," Journal of Pscyhiatric Research 8 (1971), pp. 323-333.

${ }^{40}$ Jay Weiss, "Psychological Factors in Stress and Disease," Scientific American 226 (1972), pp. 101113.

${ }^{41}$ This notion was pioneered in the early 1980's by Marian Dawkins, Ian Duncan, and myself.

42 In January of 2007, the largest pork producer in the U.S., Smithfield, announced that it is phasing out sow stalls, arguably the worst confinement agricultural practices. 